\title{
Spatial and temporal variation of phytoplankton in subtropical stabilization ponds
}

Distribuição espacial e temporal do fitoplâncton em lagoas de estabilização subtropicais

Wiviany Riediger $^{1,2}$, Norma Catarina Bueno ${ }^{1,2,3}$, Nyamien Yahaut Sebastien ${ }^{1}$,

Jascieli Carla Bortolini²

${ }^{1}$ Programa de Pós-graduação em Recursos Pesqueiros e Engenharia de Pesca, Universidade Estadual do Oeste do Paraná - Unioeste, Rua da Faculdade, 645, Bloco C, Jardim Santa Maria, CEP 85903-000, Toledo, PR, Brasil e-mail: wiviany_558@hotmail.com; nyamien@hotmail.com

${ }^{2}$ Laboratório de Ficologia, Universidade Estadual do Oeste do Paraná - Unioeste, Rua Universitária, 2019, Jardim Universitário, CEP 85819-110, Cascavel, PR, Brasil e-mail: jasci_biologa@hotmail.com

${ }^{3}$ Programa de Pós-graduação em Conservação e Manejo de Recursos Naturais, Universidade Estadual do Oeste do Paraná - Unioeste, Rua Universitária, 2019, Jardim Universitário, CEP 85819-110, Cascavel, PR, Brasil e-mail: norma.bueno@unioeste.br

\begin{abstract}
Aim: This study aimed at analyzing the phytoplankton community in two stabilization ponds of a subtropical region regarding spatial and temporal composition, richness, and abundance, as well as the respective relationships with local abiotic factors. For this purpose, we tested the hypothesis that eutrophic discharges of sewage results in the maintenance of high-density phytoplankton community, mainly Cyanobacteria and Chlorophyceae, both spatially and seasonally, as well as the occurrence of a spatial and seasonal similarity between phytoplankton richness and density in stabilization ponds. Methods: We carried out monthly samplings of the phytoplankton community and environmental variables, between March 2011 and February 2012, in two stabilization ponds located in the city of Cascavel, West Paraná State, Brazil. Results: We observed that the sampled months presented a clear distinction regarding environmental variability, which did not occur for the ponds. We identified 39 taxa, with Cyanobacteria as the most representative group both in richness and density. We records low diversity and evenness of species and low phytoplankton spatial and temporal variability without significant differences between the richness and density mean values according to the periods and sampling station. Conductivity, nutrients, dissolved oxygen and turbidity were the major structuring environmental variables of phytoplankton. Conclusion: Our results corroborated our hypotheses considering the similar spatial and temporal phytoplankton distributions because of abiotic conditions behaving similarly, as well as the direct connection of the ponds. This paper points out the importance of such studies to proper management, including cyanobacteria control and operational decisions regarding stabilization ponds and the export of undesirable inoculum for receiving water bodies.
\end{abstract}

Keywords: plankton; Cyanobacteria; shallow ponds; sewage; eutrophication.

Resumo: Objetivo: Este estudo objetivou analisar a comunidade fitoplanctônica em duas lagoas de estabilização de uma região subtropical em relação à composição, riqueza e abundância espacial e temporal, assim como sua respectiva relação com fatores abióticos locais. Para este propósito, nós testamos as hipóteses de que descargas eutróficas de esgotos resultam na manutençáo de uma alta densidade da comunidade fitoplanctônica, principalmente Cyanobacteria e Chlorophyceae, ambos espacial e sazonalmente, assim como a ocorrência de uma similaridade espacial e sazonal entre riqueza e densidade fitoplanctônica nas lagoas de estabilização. Métodos: Nós realizamos coletas mensais da comunidade fitoplanctônica e variáveis ambientais, entre março de 2011 e fevereiro de 2012, em duas lagoas de estabilizaçáo localizadas na cidade de Cascavel, oeste do estado do Paraná, Brasil. Resultados: Nós observamos que os meses amostrados apresentaram uma clara distinção em relação à variabilidade ambiental, o que não aconteceu para as lagoas. 
Nós identificamos 39 táxons, com Cyanobacteria como o grupo mais representativo, tanto em riqueza como em densidade. Nós registramos baixa diversidade e equitabilidade das espécies e baixa variabilidade espacial e temporal do fitoplâncton, sem diferenças significativas entre os valores médios de riqueza e densidade de acordo com os períodos e estaçóes de amostragem. Condutividade, nutrientes, oxigênio dissolvido e turbidez foram as principais variáveis ambientais estruturadoras do fitoplâncton. Conclusáo: Nossos resultados corroboram nossas hipóteses considerando a distribuição espacial e temporal similar do fitoplâncton devido ao comportamento similar das condiçóes abióticas bem como da conexão direta das lagoas. Este trabalho indicou a importância de tais estudos para o manejo adequado, incluindo controle de cianobactérias e as decisóes operacionais nas lagoas de estabilização e a exportação de inóculos indesejáveis para os corpos receptores.

Palavras-chave: plâncton; Cyanobacteria; lagoas rasas; esgoto; eutrofização.

\section{Introduction}

The current worldwide shortage of water resources have been the increasing result of enormous population growth and constant human intervention in the environment leading to altered quality of surface and groundwater due to the discharge of polluters. This is the scenario for the development of water reuse measures concerning the importance of rational use and controlled losses and waste.

Therefore, it is fundamental to acknowledge water as a natural asset of economic value in order to set advanced conservation able to evolve to official rules and laws regarding water resources management, which have actually been adopted and employed in many countries (Burden et al., 2004). Another consequence to this scenario is the growing concern regarding the level of treatment and the final destination of domestic and industrial sewage as well as its impact on the environment; consequently, the quality of the maintenance of water bodies to receive these substances also becomes a concern (Jordão \& Pessôa, 2005).

Sewage has high eutrophication ability due to its nutrients accumulation, such as nitrogen and phosphorus (Marques et al., 2003). In addition to nutrient loading and the chances of eutrophication of water bodies receptors, the release of these residues without any previous treatment may have deep implications on the quality of water, which could encompass alterations in chemical composition and in the food chain, damaging biodiversity as well as the ability of aquatic ecosystems to provide valuable ecosystem services for the world's population (Ferreira et al., 2005; Allan \& Castillo, 2007). Harmful algal blooms and hypoxia consist of two among the symptoms of eutrophication that are more commonly acknowledged (Liu et al., 2012).

Brazil counts with a type of treatment that has been broadly applied in wastewater, such as sewages, using stabilization ponds. It is a low-cost system regarding implementation and maintenance, being able to operate in conditions of fluctuating loads and remove organic compounds, nitrogen, phosphorus, and pathogenic microorganisms (Soldatelli \& Schwarzbold, 2010). However, in tropical and subtropical regions, the biological systems dynamics for stabilization-pond wastewater treatments may accelerate the availability of eutrophying nutrients, that is, hypereutrophic environments that under particular conditions of insolation and temperatures create conditions that favor cyanobacteria and algae blooms. Considering all these factors, building knowledge on the ecology microorganisms present in these types of treatments, such as phytoplankton, becomes fundamental to achieve control and efficiency levels able to assess the relationship with environmental conditions. It is possible to describe the actual environmental conditions by the occurrence of those alterations in phytoplankton community considering that changes in the dynamics and structure of populations are very relevant not only to the community itself, but also to assess the integrity of ecosystems (Marinho \& Huszar, 2002; Ferrareze \& Nogueira, 2006; Soldatelli \& Schwarzbold, 2010).

Despite the importance of this community in stabilization-pond treatment process for wastewater, few are the studies encompassing their treatment and assessment. Palmer (1969), Mara et al. (1983) and Pearson et al. (1987) were pioneers at studying phytoplankton community in stabilization ponds with focus on the ponds operation and maintenance. In Brazil, other researchers have developed studies with this type of environment, including the northeastern region, with Ceballos et al. (1998), Paraíba State; Cavalcanti et al. (2010), Pernambuco State; Aquino et al. (2010) and Aquino et al. (2011), Ceará State. Still, the southeast region counts with a research by Barroso et al. (1997) and 
Delazari-Barroso et al. (2009), Espírito Santo State; Furtado et al. (2009), São Paulo State; Bastos et al. (2010), Minas Gerais State. Finally, in the southern region Barthel et al. (2008), in Santa Catarina State, and Soldatelli \& Schwarzbold (2010), Rio Grande do Sul State developed their studies.

When developing this study, we considered its importance to the understanding of alterations in the phytoplankton community distribution caused by the environmental conditions of these systems. We also highlight the relevance of this community as an instrument to propose management measures for the prevention of issues concerning the quality of water in receptor bodies.

This study aimed at analyzing the phytoplankton community in two stabilization ponds of a subtropical region regarding spatial and temporal composition, richness, and abundance, as well as the respective relationships with local abiotic factors. For this purpose, we tested the hypotheses that (i) large amount of eutrophic discharges of sewage results in the maintenance of high-density phytoplankton community, mainly Cyanobacteria and Chlorophyceae, both spatially and seasonally, as well as (ii) the occurrence of a spatial and seasonal similarity between phytoplankton richness and density in stabilization ponds.

\section{Material and methods}

\subsection{Study area}

The study was carried out in the city of Cascavel, located in the West Paraná State, Brazil, with a humid subtropical climate (ITCF, 1990). The management of water supply and sewage collection in Cascavel is a concession to the Sanitation Company of Paraná - SANEPAR, with Sewage Treatment Station of Antas River. The Sewage Treatment Station of Antas River started operating in 1998, currently; approximately $188 \mathrm{l} / \mathrm{sec}$ are treated to serve around 120,000 habitants. The sewage treatment system consists of preliminary treatment (railing, sand trap, flowmeter); primary treatment (Anaerobic Fluidized Bed Reactor - RALF/UASB), and secondary treatment, which is carried out in the anaerobic and facultative stabilization ponds. After the treatment, the effluent goes to the receiver water body, which is the Bezerra stream, a tributary of the Antas River.

We defined two sampling stations: one in the anaerobic stabilization pond and the other in the facultative stabilization pond. The ponds are directly connected: i) Station 1 - anaerobic pond output (S 24⒌'11" and W 53 29'09”). Length: 208 meters, width: 112 meters, depth:
2.2 meters, and water residence time: 3.2 hours; ii) Station 2 - facultative pond output (S $24^{\circ} 55^{\prime} 05^{\prime \prime}$ and W 53 29'14”). Length: 208 meters, width: 112 meters, depth: 2 meters, and water residence time: 3 hours (Figure 1).

\subsection{Methods}

We carried out monthly samplings of the phytoplankton community and environmental variables, between March 2011 and February 2012. Phytoplankton samples were taken just below the water surface (depth $20 \mathrm{~cm}$ ) and collected directly in bottles, preserved with $1 \%$ Lugol solution. Counted fields were selected randomly, in an inverted microscope, according to Utermöhl (1958) and Lund et al. (1958). The calculation of the phytoplankton density was performed according to the American Public Health Association - APHA (1995) with results expressed in individuals for mililiters (ind $\mathrm{mL}^{-1}$ ). The index of specific diversity $\left(\mathrm{H}^{\prime}\right)$ - Shannon Index - for the phytoplankton community was estimated using Shannon $\&$ Weaver (1963); evenness (E), to measure the homogeneity level in the distribution density among species was calculated according to Pielou (1966). Species richness was considered the number of taxa per quantitative sample.

The data for dissolved oxygen - DO $\left(\mathrm{mg} \mathrm{L}^{-1}\right)$ and the water temperature $-\mathrm{WT}\left({ }^{\circ} \mathrm{C}\right)$ were obtained, respectively, in situ, using a microprocessor dissolved oxygen meter, AT 150 model, and a digital thermometer. The measurements of $\mathrm{pH}$ were obtained with an AT-300 $\mathrm{pH}$ meter, electrical conductivity - Cond $\left(\mu S \mathrm{~cm}^{-1}\right)$ with a manual conductivity model CD-820, and turbidity (NTU) with a turbidimeter model TB1000. The concentrations of total nitrogen - TN (mg L $\left.{ }^{-1}\right)$, ammonium - $\mathrm{NH}_{4}^{+}\left(\mathrm{mg} \mathrm{L}^{-1}\right)$, nitrate $-\mathrm{NO}_{3}^{-}\left(\mathrm{mg} \mathrm{L}^{-1}\right)$, nitrite $\mathrm{NO}_{2}^{-}\left(\mathrm{mg} \mathrm{L}^{-1}\right)$, total phosphorus - TP $\left(\mathrm{mg} \mathrm{L}^{-1}\right)$, soluble reactive phosphorus - SRP $\left(\mathrm{mg} \mathrm{L}^{-1}\right)$ and total solids - TS $\left(\mathrm{mg} \mathrm{L}^{-1}\right)$, were performed in the Laboratory of Limnology at the GERPEL (Study Group on Fisheries Resources and Limnology), according to the methodology described by the American Public Health Association - APHA (1995). The data of precipitation $(\mathrm{mm})$ were provided by the Meteorological Institute of Paraná (SIMEPAR, 2012), considering the values of the previous collection day added to the collection day.

A Principal Components Analysis (PCA) was performed to reduce the number of predictor variables and identify the environmental variability 


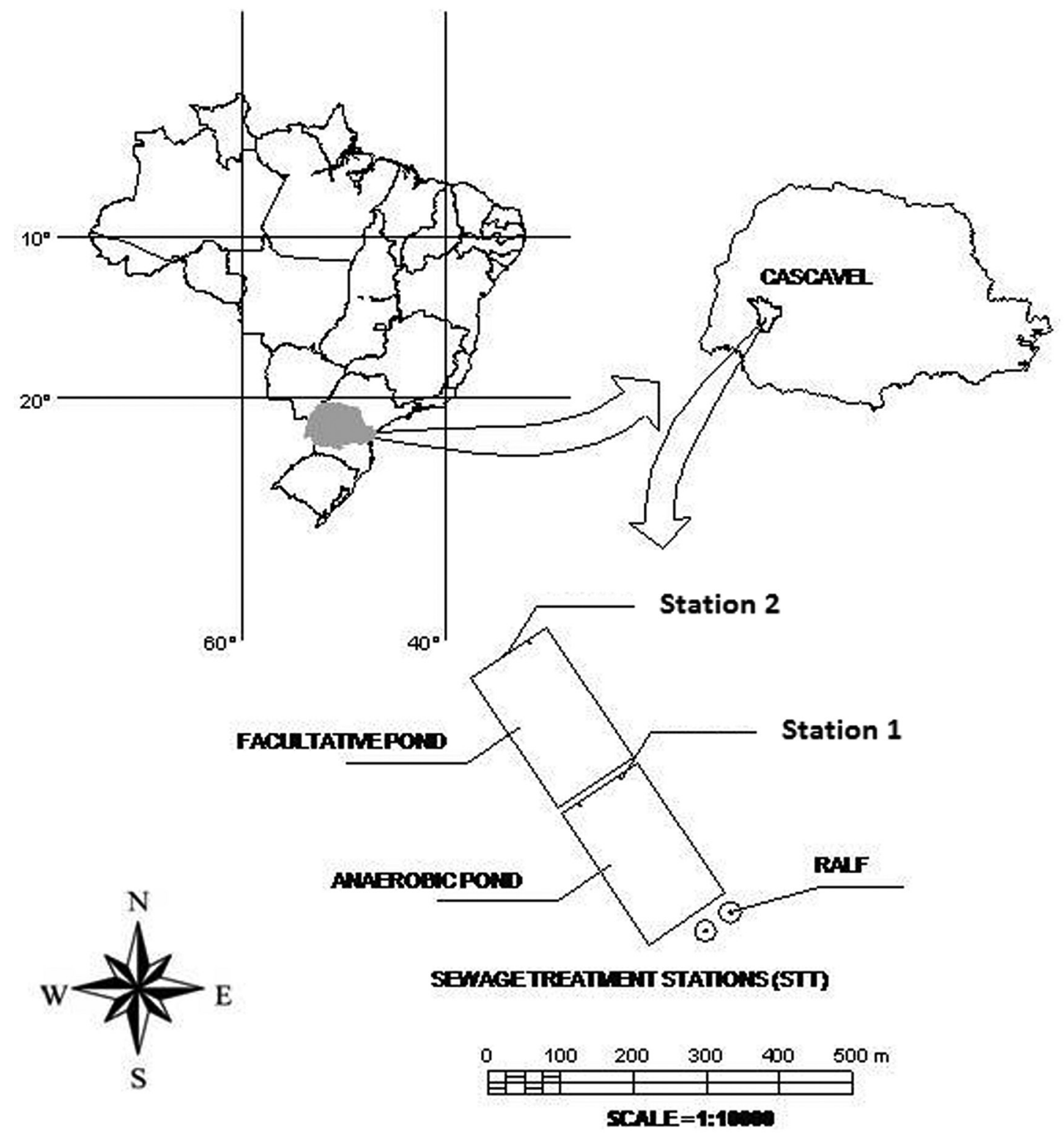

Figure 1. Map and location of sampling stations in stabilization ponds, Cascavel, Paraná, Brazil (RALF - Anaerobic Fluidized Bed Reactor - RALF/UASB, primary treatment).

in stabilization ponds. An Analysis of Variance (two-way ANOVA) was performed to test significant differences between the mean values for richness and density according periods (rainy and dry) and stations (station 1 and 2). To investigate the relationship of phytoplankton community and the environmental variability, we performed a Redundancy Analysis (RDA) using the density of all species as the response variable and environmental variables measured as the explanatory variables. The occurrence of multicollinearity between the explanatory variables was verified through the Variance Inflation Factor (VIF). We conducted the selection of variables according to Forward's selection method. ANOVA was performed using Statistica program (StatSoft Inc., 2005), while PCA and RDA were performed using R software (R Development Core Team, 2012).

\section{Results}

We observed that the sampled months presented a clear distinction regarding environmental variability, which did not occur for the ponds. Table 1 presents the minimum, maximum, and means values as well as the variation coefficient of the abiotic variables. The first two axes generated 
through the Principal Component Analysis explained $62 \%$ of the environmental variability in the stabilization ponds. The first axis had positive influenced of conductivity (0.70) and negative influenced of water temperature $(-0.92)$, TP $(-0.86)$, and SRP $(-0.82)$, discriminated between months of March to August, indicated on the right of the diagram. The principal variables in the second axis were conductivity $(0.46)$ positive, and $\mathrm{pH}(-0.88)$ negative, for other months (Figure 2).

We recorded 39 taxa (Table 2). Among the taxonomic groups recorded, Cyanobacteria (49\%) was the group with the largest number of taxa.
The other groups had less significant contributions: Chlorophyceae (18\%), Bacillariophyceae (13\%), Euglenophyceae (13\%), Chlamydophyceae (5\%), and Zygnematophyceae (3\%). Euglena (Euglenophyceae) was the genus with highest number of taxa. The months of November 2011 (Station 2) and February 2012 (Station 1) presented the highest species richness, both with 20 taxa. Cyanobacteria was the group with the largest contribution to the phytoplankton richness both spatially and temporally (Figure 3a). The stabilization ponds presented high phytoplankton density values. The maximum value of phytoplankton density verified in station

Table 1. Minimum, maximum and mean values and coefficient of variation (CV) of abiotic variables in the stabilization ponds.

\begin{tabular}{|c|c|c|c|c|c|c|c|c|c|c|c|c|c|}
\hline & & Tur & Cond & $\mathrm{pH}$ & WT & DO & TN & $\mathrm{NH}_{4}^{+}$ & $\mathrm{NO}_{2}^{-}$ & $\mathrm{NO}_{3}^{-}$ & TP & SRP & TS \\
\hline \multirow[t]{4}{*}{ Sation 1} & Minimum & 19.2 & 109.0 & 4.7 & 19.0 & 1.4 & 0.5 & 2.7 & 0.1 & 0.3 & 0.3 & 1.4 & 212 \\
\hline & Maximum & 118.0 & 775.0 & 14.0 & 26.0 & 25.2 & 5.0 & 39.7 & 0.2 & 7.1 & 4.2 & 5.5 & 813 \\
\hline & Mean & 64.3 & 561.8 & 8.1 & 21.9 & 7.7 & 1.8 & 18.0 & 0.1 & 2.0 & 2.3 & 3.3 & 472.1 \\
\hline & CV & 52.6 & 33.2 & 34.0 & 10.7 & 80.0 & 69.3 & 60.9 & 29.5 & 108.0 & 69.4 & 47.4 & 34.3 \\
\hline \multirow[t]{4}{*}{ Station 2} & Minimum & 37.9 & 210.0 & 5.8 & 19.0 & 0.9 & 0.4 & 4.7 & 0.1 & 0.2 & 0.3 & 1.3 & 291 \\
\hline & Maximum & 111.0 & 810.0 & 12.2 & 25.0 & 29.5 & 8.7 & 27.1 & 0.2 & 6.8 & 4.1 & 5.2 & 739 \\
\hline & Mean & 73.9 & 488.9 & 7.5 & 21.9 & 7.4 & 2.3 & 17.2 & 0.1 & 2.2 & 2.2 & 3.3 & 481.3 \\
\hline & cV & 35.4 & 36.1 & 19.7 & 10.8 & 103.6 & 94.9 & 52.5 & 24.4 & 92.1 & 68.9 & 44.2 & 32.0 \\
\hline
\end{tabular}

(Tur - Turbidity - NTU; Cond - electrical conductivity - $\mu \mathrm{S} \mathrm{cm}^{-1} ; \mathrm{pH}$; WT - water temperature - ${ }^{\circ} \mathrm{C}$; DO - dissolved oxygen - $\mathrm{mg} \mathrm{L}^{-1}$; $\mathrm{TN}$ - total nitrogen - $\mathrm{mg} \mathrm{L}^{-1} ; \mathrm{NH}_{4}^{+}-$ammonium - $\mathrm{mg} \mathrm{L}^{-1} ; \mathrm{NO}_{2}^{-}-$nitrite - $\mathrm{mg} \mathrm{L}^{-1}$; $\mathrm{NO}_{3}^{-}-$nitrate $^{-}$ - $\mathrm{mg} \mathrm{L}^{-1}$; TP - total phosphorus - $\mathrm{mg} \mathrm{L}^{-1} ; \mathrm{SRP}$ - soluble reactive phosphorus - $\mathrm{mg} \mathrm{L}^{-1}$; TS - total solids - $\mathrm{mg} \mathrm{L}^{-1}$ ).

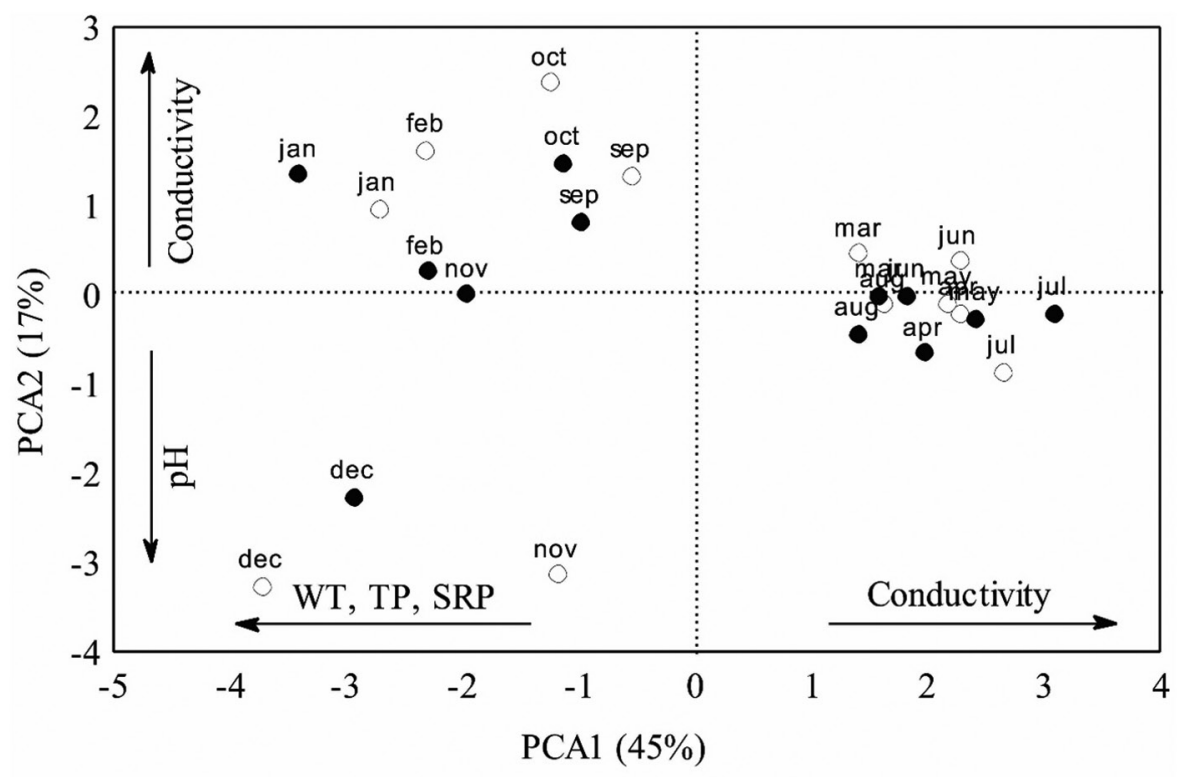

- Station 1 - Station 2

Figure 2. Dispersion of the scores of the first two axes of the Principal Component Analysis performed using the abiotic variables in the stabilization ponds (Conductivity - electrical conductivity; SRP - soluble reactive phosphorus; TP - total phosphorus; WT - water temperature; $\mathrm{pH}$; jan - January; feb - February; mar - March; apr - April; may - May; jun - June; jul - July; aug - August; sep - September; oct - October; nov - November; dec - December). 
Table 2. Phytoplankton taxa recorded in the stabilization ponds (S1 - station 1; S2 - station 2) among March 2011 to February 2012 and mean density for each taxon (ind $\mathrm{mL}^{-1}$ ).

\begin{tabular}{|c|c|c|c|}
\hline Bacillariophyceae & s1 & S2 & $\begin{array}{c}\text { Mean } \\
\text { Density }\end{array}$ \\
\hline Aulacoseira granulata (Ehrenberg) Simonsen & - & - & 34 \\
\hline Gomphonema parvulum (Kützing) Kützing & - & - & 19 \\
\hline Navicula sp. & - & - & 11 \\
\hline Nitzschia palea (Kützing.) W. Smith & • & - & 39 \\
\hline Pinnularia gibba (Ehrenber) Ehrenberg & • & • & 11 \\
\hline \multicolumn{4}{|l|}{ Cyanobacteria } \\
\hline Aphanocapsa cf. delicatissima West Et G. S. West & - & - & 2,878 \\
\hline Aphanothece sp. & - & - & 639 \\
\hline Artrosphira sp. & $\cdot$ & - & 895 \\
\hline Chroococcus minimus (Keissler) Lemmermann & - & - & 52,841 \\
\hline Chroococcus minutus (Kützing) Nageli & • & - & 7,040 \\
\hline Geitlerinema unigranulatum (R.N.Singh) J. Komárek \& M.T.P. Azevedo & - & - & 211 \\
\hline Heteroleibleinia kuetzingii (Schmidle) Compère & - & - & 568 \\
\hline Jaaginema quadripunctulatum (Brühl \& Biswas) Anagnostidis \& Komárek & - & - & 279 \\
\hline Komvophoron minutum (Skuja) Anagnostidis \& Komárek & - & - & 5 \\
\hline Leibleinia epiphytica (Hieronymus) Compère & - & - & 2 \\
\hline Leptolyngbya cf. margaretheana (G. Schmid) Anagnostidis \& Komárek & $\cdot$ & - & 6,882 \\
\hline Microcystis aeruginosa Kützing & $\cdot$ & - & 105 \\
\hline Oscillatoria subbrevis Schmidle & • & - & 93 \\
\hline Oscillatoria sancta Kützing ex Gomont & - & - & 23 \\
\hline Planktolyngbya limnetica (Lemmermann) Komárková-Legnerová \& Cronberg & $\cdot$ & • & 2,217 \\
\hline Pseudanabaena mucicola (Naumann \& Huber-Pestalozzi) Schwabe & $\cdot$ & • & 4,159 \\
\hline Pseudanabaena galeata Böcher & $\cdot$ & - & 3,859 \\
\hline Spirulina subtilissima Kützing ex Gomont & • & - & 29 \\
\hline Synechococcus nidulans (Pringsheim) Komárek & $\cdot$ & - & 1,779 \\
\hline \multicolumn{4}{|l|}{ Chlamydophyceae } \\
\hline Chlamydomonas sp. & - & - & 2,163 \\
\hline Pyrobotrys elongata Korshikov & $\cdot$ & - & 533 \\
\hline \multicolumn{4}{|l|}{ Chlorophyceae } \\
\hline Chlorococcum infusionum (Schrank) Meneghini & • & - & 35,477 \\
\hline Crucigenia tetrapedia (Kirchner) Kuntze & $\cdot$ & - & 2 \\
\hline Dictyosphaerium pulchellum Wood & $\cdot$ & • & 43 \\
\hline Golenkinia radiata Chodat & $\cdot$ & • & 100 \\
\hline Golenkiniopsis longispina (Korshikov) Korshikov & $\cdot$ & - & 204 \\
\hline Micractinium pusillum Fresenius & • & $\cdot$ & 316 \\
\hline Phytelios viridis Frenzel & - & $\cdot$ & 5 \\
\hline \multicolumn{4}{|l|}{ Euglenophyceae } \\
\hline Euglena agilis Carter & - & • & 23 \\
\hline Euglena clara Skuja & - & - & 6 \\
\hline Euglena polymorpha Dangeard & - & - & 14,685 \\
\hline Euglena sp. & $\cdot$ & • & 112 \\
\hline Lepocinclis salina Fritsch & $\cdot$ & • & 276 \\
\hline \multicolumn{4}{|l|}{ Zygnematophyceae } \\
\hline Closterium lunula Ehrenberg \& Hemprich ex Ralfs & - & - & 2 \\
\hline
\end{tabular}

1 was 337,284 ind $\mathrm{mL}^{-1}$, while the minimum density value recorded was 54,418 ind $\mathrm{mL}^{-1}$ with a mean value of 138,242 ind $\mathrm{mL}^{-1}$. In station 2 , the maximum density value verified was 252,870 ind $\mathrm{mL}^{-1}$ and minimum density value recorded was 79,511 ind $\mathrm{mL}^{-1}$ with a mean value of 138,893 ind $\mathrm{mL}^{-1}$. The month of February 2012 presented the highest values of phytoplankton abundance at Station 1, with high contribution of Cyanobacteria, especially Pseudanabaena mucicola (Hüb.-Pest. e Naum.) Bourr. (Figure 3b). Cyanobacteria, Chlorophyceae and Euglenophyceae were the most abundant groups.

According to ANOVA, the mean values for both the phytoplankton richness $(p=0.65)$ and density $(p=0.26)$ did not reveal significant differences 

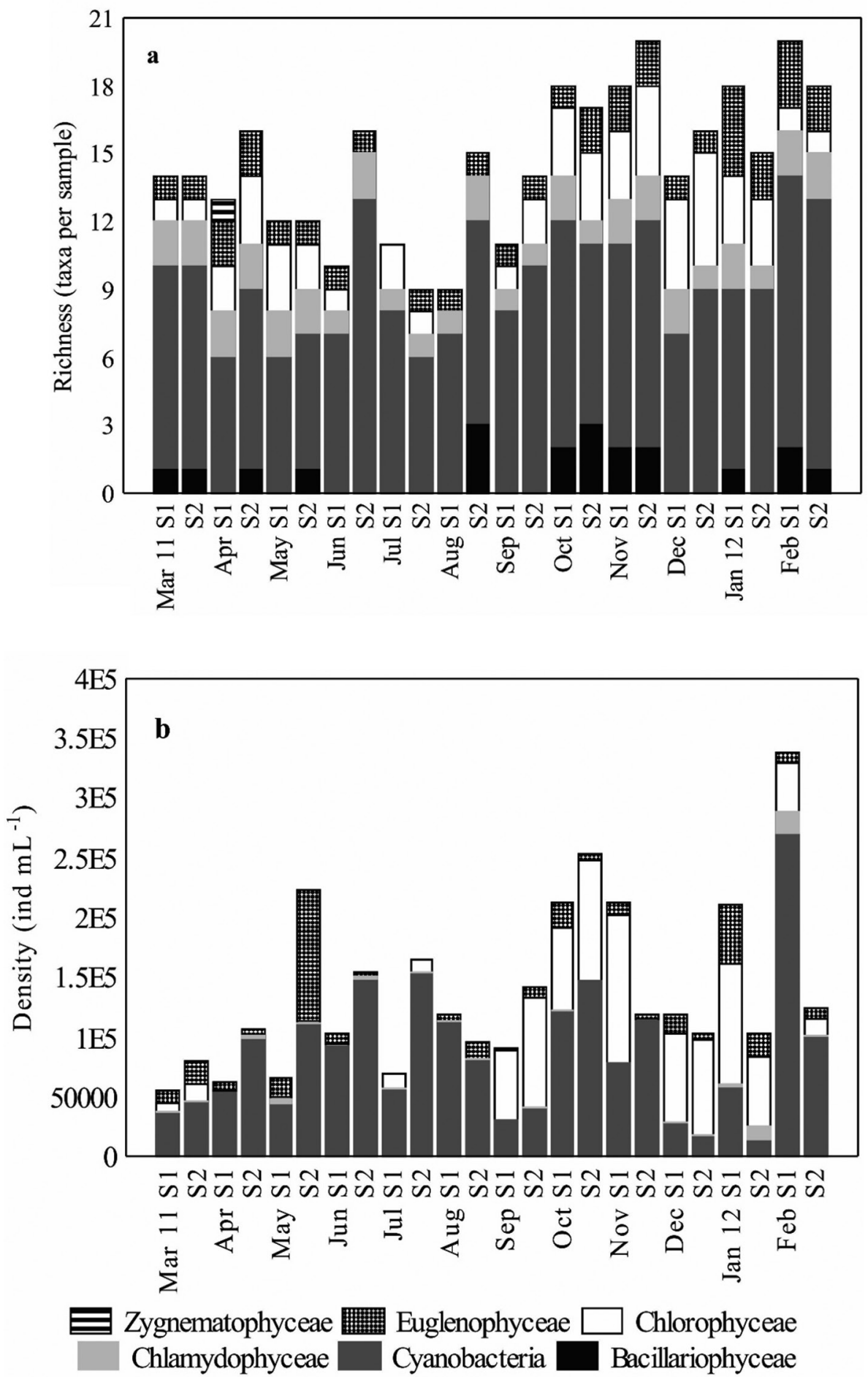

Figure 3. Temporal and spatial variation of the richness (a) and density (b) phytoplankton in stabilization ponds.

according to the period and sampling station (Figure 4a-b). Most of the sampled months had low values of Shannon diversity and evenness (Figure 5).

The Redundancy Analysis indicated similar density values for phytoplankton species along the studied period explaining $54 \%$ of the data variance $(p=0.01)$, with axis 1 explaining $34 \%$ of the variability of the data and the axis 2 explaining only $6 \%$, where exclusively axis 1 proved significant $(p=0.001)$. The species presented low dispersion of scores, being only Chroococcus minimus (Keissler) Lemmermann separate on the right portion of the diagram, with positive influence of conductivity (0.55), which separated the months from March 

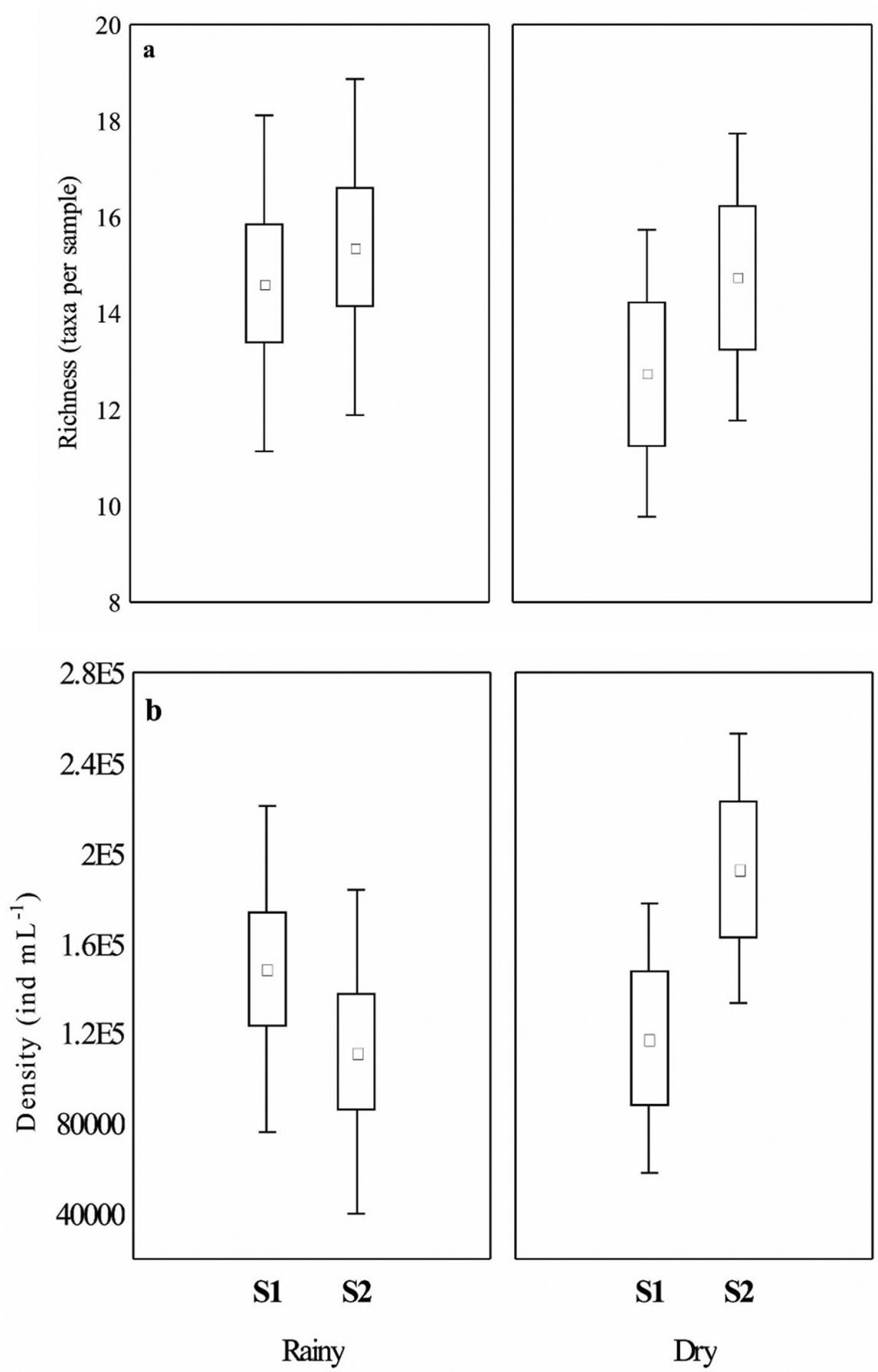

Rainy Dry

$\square$ Mean $\square$ Mean \pm SE I Mean \pm SD

Figure 4. Mean values and standard deviation of the richness (a) and density (b) phytoplankton in stabilization ponds.

to July. In contrast, the negative influence on the axis 1 of $\mathrm{NO}_{3}^{-}(-0.70)$, SRP $(-0.72)$ and DO $(-0.52)$ caused the discrimination in the diagram left portion for Chlorococcum infusionum (Schrank) Meneghini. In addition, the diagram left portion present the months with positive correlation to turbidity (0.53) and $\mathrm{NH}_{4}^{+}(0.70)$ in axis 2 (Figure 6) separately.

\section{Discussion}

Stabilization ponds can be considered lentic, shallow and hipereutrophic ecosystems because of the high organic discharge that this type of environment receives. They present short hydraulic residence time, high values of electrical conductivity, high turbidity, high total solids, and high phytoplankton density, representing good 


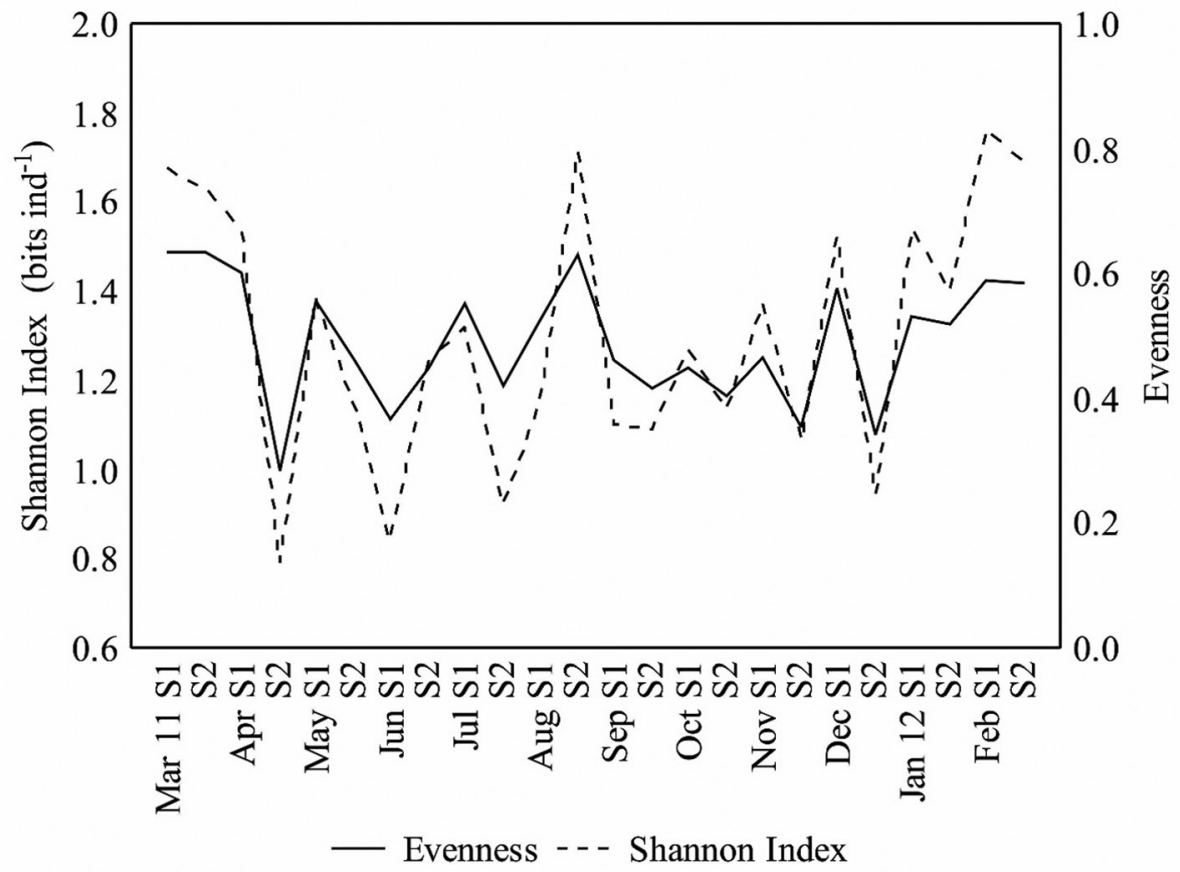

Figure 5. Spatial and temporal variation of the Shannon diversity and evenness in the stabilization ponds.

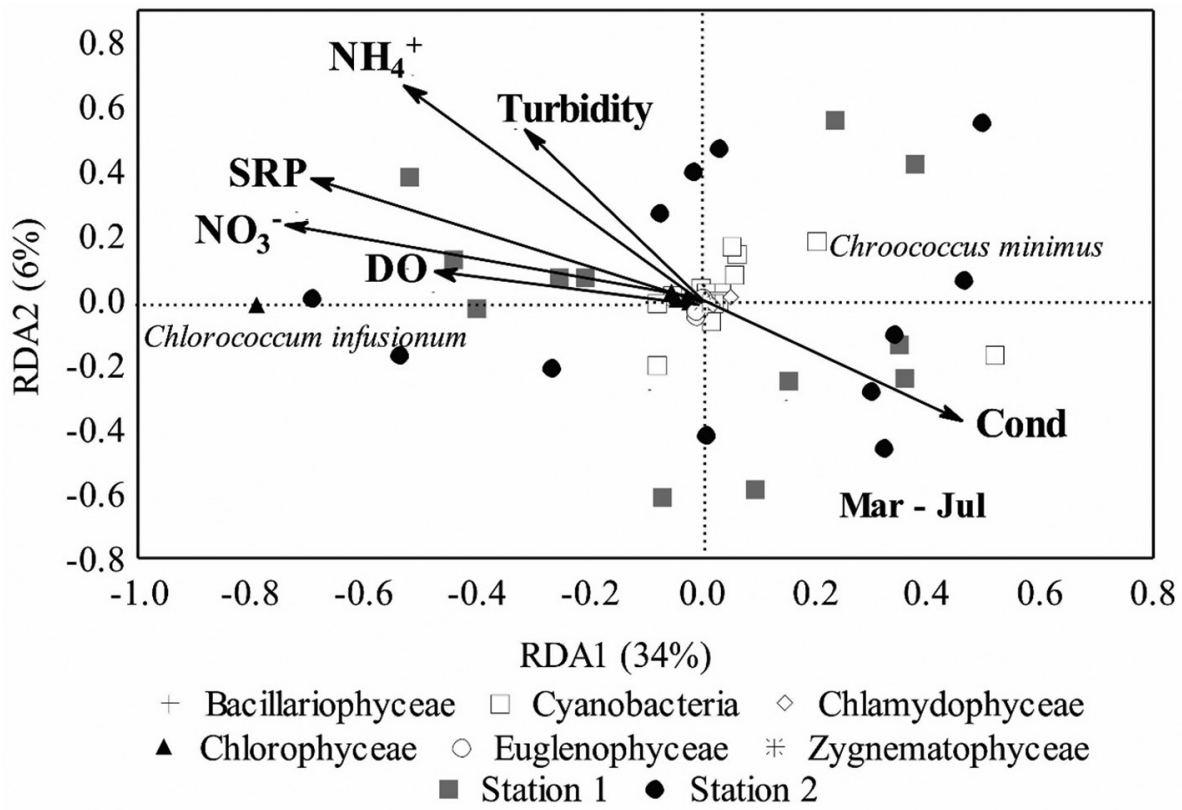

Figure 6. Diagram of the first and second RDA axes based on the density of species, including all samples from March 2011 to February 2012, and environmental variables (Turbidity; DO - dissolved oxygen; SRP - soluble reactive phosphorus; Cond - electrical conductivity; $\mathrm{NO}_{3}{ }^{-}$- nitrate; $\mathrm{NH}_{4}^{+}{ }^{+}$ammonium; Mar - March; Jul - July).

models to understand the phytoplankton dynamics under such conditions, as demonstrated in our study.

The low values of richness, species diversity, and evenness in most of the analyzed months, as well as high phytoplankton density, are likely to have occurred due to the extreme limnological conditions observed in these ponds, which results in the presence and dominance of only a few taxa. According to Tundisi \& Matsumara-Tundisi (2008), the habitat-selection behavior of species, the interaction with other species, and tolerance to physical and chemical factors lead to a small amount of species with conditions to develop 
populations in these environments. However, it should be considered that lower biodiversity may decrease the magnitude and stability of the ecosystem processes, such as the use of resources and productivity (Cottingham et al., 2001; Ptacnik et al., 2008). Delazari-Barroso et al. (2009) had reported such event in Brazil, with 38 taxa in the polishing ponds; Aquino et al. (2011) also identified 22 phytoplankton taxa in the facultative pond.

Cyanobacteria had a major contribution regarding both richness (mean of 9 taxa per sample) and phytoplankton abundance (high contribution of Pseudanabaena mucicola in February 2012), which may be common in this type of environment, where it prevails over other phytoplankton groups (Furtado et al., 2009). This could be associated with conditions of water temperature and low $\mathrm{CO}_{2}$ concentration (Dokulil \& Teubner, 2000; Huszar et al., 2000), the addition of high nutrient concentrations (Sant'Anna et al., 2008), and water column stability. In tropical and subtropical regions, the dynamics of stabilization-pond biological treatment accelerates the availability of eutrophying nutrients, which, synergistically at higher temperatures and long periods of light, create essential conditions for the development of excessive cyanobacteria populations.

In addition to this group, Chlorophyceae stands out with its taxa richness in meso-eutrophic and shallow environments (Tucci et al., 2006). Chlorophyceae are considered opportunistic for their small size and rapid growth, favoring its presence in any season of the year (Happey-Wood, 1988). Chlorophyceae include organisms that are particular to different types of environments, from oligotrophic waters to heavily polluted environments because of many survival strategies resulting from high diversity (Peres $\&$ Senna, 2000). This was evidenced in the present study by RDA with the presence and important contribution of Chlorococcum infusionum (Schrank) Meneghini in many of the analyzed months, which has optimal conditions for development in enriched and turbid environments (Reynolds et al., 2002; Padisák et al., 2009) as the ponds stabilizations studied.

We verified an important contribution of Chlamydophyceae (mainly Chlamydomonas sp.), c-strategist, in both ponds, as observed by Aquino et al. (2011). These organisms are abundant in shallow water bodies with higher concentration of nutrients (Padisák et al., 2009). Also, Euglenophyceae presented important contributions to phytoplankton density mainly due to the presence of Euglena polymorpha Dangeard var. polymorpha. This group consists of facultative heterotrophic organisms able to perform photosynthesis in the euphotic layer, or mineralize organic compounds in aphotics layers (Reynolds et al., 2002; Padisák et al., 2009). Therefore, the presence of suspended and dissolved solids may cause a decrease in light penetration in the water column, favoring euglenoids in some periods.

The reason for the substitution species account with the balance of species that coexistence in the environments (Tilman, 1982), as well as with the non-equilibrium in environmental variability that causes the species competition for the same resources (Richerson et al., 1970). The successive and continuous colonization of a site by a certain species populations, along with the extinction of another, is understood as ecological succession, which applies to phytoplankton (Reynolds, 1988, 1998).

The process referred to as succession consists of species that were originally well adapted to a habitat, but may lose their abilities and be consequently substituted by other species with better adaptation to new conditions (Lampert \& Sommer, 2007). Succession was observed in the density of phytoplankton groups, with the initial colonization of this annual cycle of studies marked with the presence of cyanobacteria, but after September, it occurred a Chlorophyceae increase, the start of a significant contribution to the phytoplankton density.

The RDA revealed similar spatial and temporal distributions throughout the study period, which probably occurred because of similar behaviors of abiotic conditions (stable environment), along with the environment chemical composition; in addition, the direct connection of the ponds influenced phytoplankton spatial distribution. Furthermore, the availability of nutrients in the stabilization ponds is not a limiting factor for algal growth - available in high concentrations throughout the study period, which may have favored phytoplankton similarity, especially with presence of Cyanobacteria and Chlorophyceae.

The high conductivity values recorded in stabilization ponds probably occurred due to the action of organic matter decomposers releasing ammonium into the water, increasing the ionic concentration that is reflected in conductivity (Wetzel, 1993) and influences the discrimination of some months, as identified through the PCA, 
as well as the presence of Chroococcus minimus (Keissler) Lemmermann, as identified through the RDA. Furthermore, the warm period of the year indicates an increase in the contribution of nitrogen and phosphorus in the ponds, probably because of greater supply of organic material of anthropogenic origin. In addition to these factors, stabilization ponds are also influenced by rain, wind, and solar heating.

In conclusion, the studied sites did not present marked differences in phytoplankton compositions (low spatial variability); in turn, a homogeneous distribution of the species was observed throughout the sampling period (low temporal variability), with high contribution of Cyanobacteria and Chlorophyceae, corroborating our hypotheses. This study may indicate the effluent resulting from sewage treatment along the year represented majorly by Cyanobacteria. Some of these phytoplankton organisms can be considered potentially toxic and should be emphasized along with the implementation of management measures for this wastewater in order to prevent inoculum toxigenic from entering the receiving water bodies, such as rivers and streams, once cyanobacteria threaten the ecological integrity and sustainability of aquatic ecosystems that depend on drinking water, irrigation, fishing, and recreation (Paerl \& Otten, 2013).

The consequence is that the protection of worldwide freshwater requires a diagnosis of the threats to biodiversity, and the success of water management relies on the balance between the use of these resources and ecosystem protection measures. This type of study is essential to provide subsidies for proper management, including control of cyanobacteria and decisions on the operation of stabilization ponds as well as the introduction of undesirable inoculum into water bodies.

\section{Acknowledgements}

The authors would like to thank the Coordenação de Aperfeiçoamento de Pessoal de Nível Superior - CAPES for providing scholarship to WR and Conselho Nacional de Pesquisa e Desenvolvimento - CNPq for providing post-doctoral scholarship to JCB. NCB is grateful to the CNPq of Brazil for a Research Productivity Grant (process 307196/2013-5).

\section{References}

ALLAN, J.D. and CASTILLO, M.M. Stream Ecology: structure and function of running waters. 2 nd ed. Heidelberg: Springer, 2007, 436 p.
AMERICAN PUBLIC HEALTH ASSOCIATION - APHA. Standart methods for the examination of water and wasterwater. 19th ed. Washington: APHA, 1995, $541 \mathrm{p}$.

AQUINO, E.P., LACERDA, S.R. and FREITAS, A.I.G. Cianobactérias das lagoas de tratamento de esgoto no semi-árido nordestino (Ceará, Brasil). Le Journal de Botanique, 2010, 39(1), 34-46.

AQUINO, E.P., OLIVEIRA, E.C.C., FERNANDES, U.L. and LACERDA, S.R. Fitoplâncton de uma lagoa de estabilização no nordeste do Brasil. Brazilian Journal of Aquatic Science and Technology, 2011, 15(1), 71-77. http://dx.doi.org/10.14210/bjast. v15n1.p71-77.

BARROSO, G.F., DIAS-JR, C. and GÜNTZEL, A. Preliminary assessment of the eutrophication potential of sewage effluents of four wastewater treatment plants in Espírito Santo State (Brazil). Verhandlungen des Internationalen Verein Limnologie, 1997, 26, 666-670.

BARTHEL, L., OLIVEIRA, P.A.V. and COSTA, R.H.R. Plankton Biomass in secondary ponds treating piggery waste. Brazilian Archives of Biology and Technology, 2008, 51(6), 1287-1298. http://dx.doi. org/10.1590/S1516-89132008000600025.

BASTOS, R.K.X., DORNELAS, F.L., RIOS, E.M. and OKANO, W.Y. Dinâmica da qualidade da água e da comunidade planctônica em lagoas de polimento: estudo de caso no sudeste brasileiro. Revista Aidis de Ingeniería y Ciencias Ambientales: Investigación, desarrollo y práctica, 2010, 3(1), 97-107.

BURDEN, F.R., DONNERT, D., GODISH, T. and MC KELVIE, I. Environmental monitoring handbook. New York: McGraw-Hill, 2004, 1100 p.

CAVAlCANTI, A.L.A., CAMPELO, M.J.A. and GAMA, T.C.C. Microalgas em lagoas de estabilização do semiárido pernambucano e suas implicaçóes na saúde: um estudo de caso em Petrolina - PE. Enciclopédia Biosfera: Centro Cientifico Conhecer, 2010, 6(10), 1-10.

CEBALlOS, B.S.O., DINIZ, C.R. and KÖNIG, A. Algas como bioindicadores do nível trófico de ecossistemas lênticos do semi-árido paraibano. Revista Engenharia Sanitária e Ambiental, 1998, 3(3), 137-145.

COTTINGHAM, K.L., BROWN, B.L. and LENNON, J.T. Biodiversity may regulate the temporal variability of ecological systems. Ecology Letters, 2001, 4(1), 72-85. http://dx.doi.org/10.1046/j.14610248.2001.00189.x.

DELAZARI-BARROSO, A., OLIVEIRA, F.F., MARQUES, M.A.M. and SANTOS, S.M. Avaliação Temporal do Fitoplâncton na Lagoa de Polimento de uma Estação de Tratamento de Esgoto do Tipo Biossistemas Integrados, em Alto Caxixe, Venda Nova do Imigrante, ES, Brasil. Revista Cientifica Faesa, 
2009, 5(1), 7-16. http://dx.doi.org/10.5008/18097367.021 .

DOKULIL, M.T. and TEUBNER, K. Cyanobacterial dominance in lakes. Hydrobiologia, 2000, 438(1/3), 1-12. http://dx.doi.org/10.1023/A:1004155810302.

FERRAREZE, M. and NOGUEIRA, M.G. Phytoplankton assemblages in lotic systems of the Paranapanema Basin (Southeast Brazil). Acta Limnologica Brasiliensia, 2006, 18(4), 389-405.

FERREIRA, R.A.R., CAVENAGHI, A.L., VELINI, E.D., CORREAA, M.R., NEGRISOLI, E., BRAVIN, L.F.N., TRINDADE, M.L.B. and PADILHA, F.S. Monitoring phytoplankton and microcistyn at the Americana reservoir. Planta Daninha, 2005, 23(2), 203-214. http://dx.doi.org/10.1590/S010083582005000200006 .

FURTADO, A.L.F.F., CALIJURI, M.C., LORENZI, A.S., HONDA, R.Y., GENUÁRIO, D.B. and FIORE, M.F. Morphological and molecular characterization of cyanobacteria from a Brazilian facultative wastewater stabilization pond and evaluation of microcystin production. Hydrobiologia, 2009, 627(1), 195-209. http://dx.doi.org/10.1007/ s10750-009-9728-6.

HAPPEY-WOOD, C. Ecology freshwater planktonic green algae. In C.D. SANDGREN, ed. Growth and reproductive strategies of freshwater phytoplankton. Cambridge: University Press, 1988, 452 p.

HUSZAR, V.L.M., SILVA, L.H.S., DOMINGOS, P. and SANT'ANNA, C.L. Cyanoprokaryote assemblages in eight productive tropical Brazilian water. Hydrobiologia, 2000, 424(1-3), 67-77. http:// dx.doi.org/10.1023/A:1003996710416.

INSTITUTO DE TERRAS CARTOGRAFIA E FLORESTAS - ITCF. Atlas do Estado do Paraná. Curitiba: ITCF, 1990, 73 p.

INSTITUTO TECNOLÓGICO SIMEPAR SIMEPAR. 2012 [viewed 16 June 2012]. Available from: http://www.simepar.br/tempo/clima/clima.jsp

JORDÁO, E.P. and PESSÔA, C.A. Tratamento de esgotos domésticos. 4th ed. Rio de Janeiro: ABES, 2005, 432 p.

LAMPERT, W. and SOMMER, U. Limnoecology: the Ecology of Lakes and Streams. 2nd ed. Oxford: Oxford University Press, 2007, 324 p.

LiU, C., KROEZE, C., HOEKSTRA, A.Y. and GERBENS-LEENES, W. Past and future trends in grey water footprints of anthropogenic nitrogen and phosphorus inputs to major world rivers. Ecological Indicators, 2012, 18, 42-49. http://dx.doi. org/10.1016/j.ecolind.2011.10.005.

LUND, J.W.G., KIPLING, C. and LECREN, E.D. The invetted microscope method of estimating algal number and the statistical basis of estimating by couting. Hydrobiologia, 1958, 11(2), 980-985. http:// dx.doi.org/10.1007/BF00007865.
MARA, D.D., PEARSON, H.W. and SILVA, A.S. Brazilian stabilization pond research suggest low-cost urban application. World Water, 1983, 6(7), 20-24.

MARINHO, M.M. and HUSZAR, V.L.M. Nutrient availability and physical conditions as controlling factors of phytoplankton composition and biomass in a tropical reservoir (Southeastern Brazil). Archiv für Hydrobiologie, 2002, 153, 443-468.

MARQUES, P.H.C., OLIVEIRA, H.T. and MACHADO, E.C. Limnological study of Piraquara river (Upper Iguaçu basin): spatio-temporal variation of physical and chemical variables and watershed zoning. Brazilian Archives of Biology and Technology, 2003, 46(3), 383-394. http://dx.doi.org/10.1590/ S1516-89132003000300010.

PADISÁK, J., CROSSETTI, L.O. and NASELLIFLORES, E.L. Use and misuse in the application of the phytoplankton functional classification: a critical review with updates. Hydrobiologia, 2009, 621(1), 1-19. http://dx.doi.org/10.1007/s10750008-9645-0.

PAERL, H.W. and OTTEN, T.G. Harmful Cyanobacterial blooms: causes, consequences, and controls. Microbial Ecology, 2013, 65(4), 995-1010. http://dx.doi.org/10.1007/s00248-012-0159-y. PMid:23314096.

PALMER, C.M. A composite rating of algae tolerating organic pollution. Journal of Phycology, 1969, 1(5), 78-82. http://dx.doi.org/10.1111/j.1529-8817.1969. tb02581.x.

PEARSON, H.W., MARA, D.D., KÖNIG, A., OLIVEIRA, R., MILLS, S.W., SMALLMAN, D.J. and SILVA, S.A. Water column sampling as a rapid and efficient method of determining effluent quality and the performance of waste stabilization pond system. Water Science and Technology, 1987, 19(12), 109-113.

PERES, A.C. and SENNA, P.A.C. Chlorophyta da Lagoa do Diogo. In J.E. SANTOS and J.S.R. PIRES, eds. Estudos integrados em Ecossistemas: Estação Ecológica de Jataí. São Carlos: RiMa, 2000, pp. 469-481, vol. 2.

PIELOU, E.C. The measurement of diversity in different types of biological collection. Journal of Theoretical Biology, 1966, 1(13), 131-144. http://dx.doi. org/10.1016/0022-5193(66)90013-0.

PTACNIK, R., SOLIMINI, A.G., ANDERSEN, T., TAMMINEN, T., BRETTUM, P., LEPISTO, L., WILLÉN, E. and REKOLAINEN, S. Diversity predicts stability and resource use efficiency in natural phytoplankton communities. Proceedings of the National Academy of Sciences of the United States of America, 2008, 105(13), 5134-5138. http://dx.doi. org/10.1073/pnas.0708328105. PMid:18375765.

R DEVELOPMENT CORE TEAM. A language and environment for statistical computing [online]. Austria: R Foundation for Statistical Computing, 
2012 [viewed 05 Feb. 2013]. Available from: http:// www.R-project.org

REYNOLDS, C.S. Concept of ecological succession applied to seasonal periodicity of freshwater phytoplankton. International Vereinigung fuer Theoretische und Angewandte Limnologie, 1988, 23(2), 683-691.

REYNOLDS, C.S. What factors influence the species composition of phytoplankton in lakes of different trophic status? Hydrobiologia, 1998, 369/370, 11-26. http://dx.doi.org/10.1023/A:1017062213207.

REYNOLDS, C.S., HUSZAR, V., KRUK, C., NASELLI-FLORES, L. and MELO, S. Towards a functional classification of the freshwater phytoplankton. Journal of Plankton Research, 2002, 24(5), 417-428. http://dx.doi.org/10.1093/ plankt/24.5.417.

RICHERSON, P., ARMSTRONG, R. and GOLDMAN, C.R. Contemporaneous disequilibrium, a new hypothesis to explain the "Paradox of Plankton". Proceedings of the National Academy of Sciences of the United States of America, 1970, 67(4), 17101714. http://dx.doi.org/10.1073/pnas.67.4.1710. PMid:5275371.

SANT'ANNA, C.L., AZEVEDO, M.T.P., WERNER, V.R., DOGO, C.R., RIOS, F.R. and CARVALHO, L.R. Review of toxic species of cyanobacteria in Brazil. Algological Studies, 2008, 126(1), 251-265. http://dx.doi.org/10.1127/1864-1318/2008/01260251 .
SHANNON, C.E. and WEAVER, W. The mathematical theory of communication. Illinois: University Press Urbana, 1963, $144 \mathrm{p}$.

SOLDATELLI, V.F. and SCHWARZBOLD, A. Comunidade fitoplanctônica em lagoas de maturação, Caxias do Sul, Rio Grande do Sul, Brasil. Iheringia. Série Botânica, 2010, 65(1), 75-86.

STATSOFT INC. Statistica (data analysis software system) version 7.1 [online]. Vienna: StatSoft INC., 2005 [viewed 25 Jan. 2013]. Available from: www. statisoft.inc

TILMAN, D. Resource competition and community structure. Princeton: Princeton University Press, 1982, $296 \mathrm{p}$.

TUCCI, A., SANT'ANNA, C.L., GENTIL, R.C. and AZEVEDO, M.T.P. Fitoplâncton do Lago das Garças, São Paulo, Brasil: um reservatório urbano eutrófico. Hoehnea, 2006, 33(2), 147-175.

TUNDISI, J.G. and MATSUMARA-TUNDISI, T.M. Limnologia. São Paulo: Editora Oficina de Textos, 2008, 632 p.

UTERMÖHL, H. Zur Vervollkommnung der quantitativen phytoplankton-methodic. Mitteilungen Internationale Vereinigung für Theoretische und Angewandte Limnologie, 1958, 9, 1-38.

WETZEL, R.G. Limnologia. Lisboa: Fundação Calouste Gulbenkian, 1993, 919 p.

Received: 29 September 2015 Accepted: 01 April 2016 